Northwestern Pritzker School of Law

Northwestern Pritzker School of Law Scholarly Commons

JCLC Online

Spring 2021

American Law Enforcement Responses to COVID-19

Matthew B. Kugler

Mariana Oliver

Jonathan Chu

Nathan R. Lee

Follow this and additional works at: https://scholarlycommons.law.northwestern.edu/jclc_online

Part of the Criminal Law Commons 


\title{
AMERICAN LAW ENFORCEMENT RESPONSES TO COVID-19
}

\author{
MATTHEW B. KUGLER, MARIANA OLIVER, JONATHAN \\ CHU, AND NATHAN R. LEE*
}

I. POTENTIAL FOR LAW ENFORCEMENT INVOLVEMENT .... 19

II. SURVEY OF LOCAL POLICE DEPARTMENTS...................... 25

CONCLUSION ...................................................................... 30

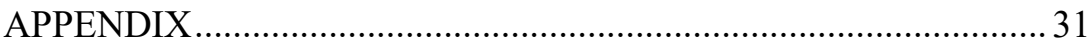

What role did law enforcement play in promoting COVID-19 restrictions in the United States during the spring and summer of 2020? Because most law enforcement in the U.S. occurs at the local level, we surveyed local police departments to examine their responses to the COVID19 pandemic. Our results show that most departments, especially those in smaller jurisdictions, played a minimal role in enforcing COVID-related restrictions and tended only to encourage compliance. Further, it was extremely rare for a department to use sophisticated surveillance technology to monitor COVID compliance. This lack of monitoring stands both in stark contrast to the regimes employed by several comparable industrialized countries and in spite of the broad surveillance powers permissible under the U.S. Constitution.

\section{POTENTIAL FOR LAW ENFORCEMENT INVOLVEMENT}

In March 2020, state governments and municipalities across the United States began to issue orders in response to the COVID-19 pandemic. At first, these orders closed nonessential businesses and instructed large portions of

* Matthew B. Kugler is an Associate Professor of Law at Northwestern Pritzker School of Law. Mariana Oliver is a JD/PhD candidate at Northwestern University. Jonathan Chu is a Lecturer at Stanford University and Director of Research at CivicPulse. Nathan R. Lee is an Assistant Professor of Public Policy at the Rochester Institute of Technology and Managing Director at CivicPulse. The authors thank David Schwartz and Nadav Shoked for their helpful comments on earlier drafts of this manuscripts, and Ann Herman and Joel Mackler for research assistance. 
the population to stay at home. ${ }^{1}$ Starting in May 2020, these blanket prohibitions were peppered with increasing nuance as portions of the country engaged in phased reopening. ${ }^{2}$

Some COVID-related restrictions were effectively self-enforcing. If a municipality ordered its schools closed, then the schools were closed. But many COVID-19 restrictions required compliance by and cooperation from non-governmental actors. Private businesses needed to close. People needed to stay in their homes. And those who left their homes needed to wear masks and avoid unnecessary (by some definition of "unnecessary") contact.

The best research available at this early date suggests that the moderate social distancing restrictions put in place were very useful in slowing the spread of COVID-19. ${ }^{3}$ But important questions remain about the relative importance of government action versus voluntary compliance in achieving social distancing, and the extent to which governments could have improved compliance where such policies were enacted. ${ }^{4}$

In this study, we examine the role of law enforcement in promoting community compliance with COVID-19 restrictions. To what extent did American law enforcement engage in community interventions? And, when they did intervene, what exactly did they do?

In many other countries, government agents used mass surveillance tools to monitor compliance with COVID-19 orders. Countries such as Taiwan, Singapore, Austria, and South Korea used cellphone location datasometimes GPS, sometimes Bluetooth - to track the movements of infected people and enforce quarantine orders. ${ }^{5}$ In Israel, France, and China,

${ }^{1}$ For a review of which restrictions were in place in which states at which times, see, e.g., Lindsay K. Cloud, Katie Moran-McCabe, Elizabeth Platt, \& Nadya Prood, A Chronological Overview of the Federal, State, and Local Response to COVID-19, in ASSESSING THE LEGAL RESPONSES To COVID-19 10-16 (Scott Burris, Sarah de Guia, Lance Gable, Donna Levin, Wendy Parmet, \& Nicholas Terry eds., 2020).

${ }^{2}$ See id.

${ }^{3}$ See, e.g., Evan Anderson \& Scott Burris, Is Law Working? A Brief Look at the Legal Epidemiology of COVID-19, in ASSESSING THE LegAl ReSPONSES TO COVID-19, 20,23 (Scott Burris, Sarah de Guia, Lance Gable, Donna Levin, Wendy Parmet, \& Nicholas Terry eds., 2020).

4 See id.

${ }^{5}$ Isobel Asher Hamilton, Compulsory selfies and contact-tracing: Authorities everywhere are using smartphones to track the coronavirus, and it's part of a massive increase in global surveillance, BUSINESS INSIDER (Apr. 14, 2020, 11:30 AM), https://www.businessinsider.com/ countries-tracking-citizens-phones-coronavirus-2020-3 [https://perma.cc/6S8L-9KMP]; Kareem Fahim, Min Joo Kim \& Steve Hendrix, Cellphone monitoring is spreading with the coronavirus. So is an uneasy tolerance of surveillance, WASHINGTON POST (May 2, 2020, 3:12 $\mathrm{PM})$, https://www.washingtonpost.com/world/cellphone-monitoring-is-spreading-with-the- 
governments used drones to ensure people with COVID-19 were following stay-at-home orders. ${ }^{6}$ And these technologies could be highly efficient. If you are not supposed to leave your home except for essential activities, then your cellphone's location tracking will rapidly betray you. If people are not supposed to be gathering in public spaces, then video surveillance footage and drones may be a cost-effective way of spotting crowds.

It is common in legal scholarship to talk about the broad range of law enforcement surveillance that is permissible under the U.S. Constitution. Many papers have reflected on the possibilities of facial recognition, drone surveillance, and cellphone tracking. ${ }^{7}$ In general, there would be little constitutional problem with using some of these techniques for COVIDmonitoring purposes. Government aerial surveillance, which presumably includes drone surveillance, was held to be permissible without a warrant decades ago. ${ }^{8}$ Warrantless use of surveillance cameras in public places has been repeatedly held to be constitutional, though a minority of courts have expressed skepticism about long-term warrantless watching of an individual house. ${ }^{9}$ And law enforcement's use of facial recognition is likely

coronavirus-so-is-an-uneasy-tolerance-of-surveillance/2020/05/02/56f14466-7b55-11 eaa311-adb1344719a9_story.html [https://perma.cc/3YPV-TXPS].

6 Joseph Krauss, Israeli Police Use Drones to Enforce Virus Quarantines, TIMES of ISRAEL (Apr. 14, 2020, 10:43 PM), https://www.timesofisrael.com/israeli-police-usingdrones-to-enforce-coronavirus-quarantines/ [https://perma.cc/XS85-7XCW].

7 Andrew Ferguson, Facial Recognition and the Fourth Amendment, 105 MinN. L. REv. (forthcoming 2020) (facial recognition); Emma Lux, Privacy in the Dumps: Analyzing Cell Tower Dumps Under the Fourth Amendment, 57 Amer. CRIM L. Rev. 109, 109-18 (2020) (cellphone tracking and tower dumps); Alisa Smith, Sean Madden, \& Robert P. Barton, An Empirical Examination of Societal Expectations of Privacy in the Digital Age of GPS, Cell Phone Towers, \& Drones, 26 ALB. L.J. SCI. \& TECH. 111, 132 (2016) (various technologies); Matthew B. Kugler \& Thomas H. Rousse, The Privacy Hierarchy: Trade Secret and Fourth Amendment Expectations, 104 IowA L. Rev. 1223, 1273-82 (2019) (use of various technologically enabled visual surveillance techniques, including high powered cameras and drones).

8 See, e.g., California v. Ciraolo, 476 U.S. 207, 213 (1986); Florida v. Riley, 488 U.S. 445, 450-51 (1989).

9 See, e.g., United States v. Houston, 813 F.3d 282, 287-88 (6th Cir. 2016); United States v. Jackson, 213 F.3d 1269, 1281 (10th Cir. 2000) (holding that a pole camera is not a search even if it observes the curtilage of a property), cert. granted, judgment vacated on other grounds, 531 U.S. 1033 (2000). But see Kugler \& Rousse, supra note 7, at 1277-79 (describing the judicial discomfort with this result and a potential for a split of authority on the topic). 
constitutionally permissible even though there are good policy arguments that its use should be restrained. ${ }^{10}$

The only COVID-monitoring technology subject to substantial legal controls is cellphone location data. Use of long-term historic cellphone location data for criminal investigations requires a warrant. ${ }^{11}$ Nevertheless, cellphone location data is regularly used in criminal investigationspresumably via court-approved channels - so this regulation hardly amounts to a ban. ${ }^{12}$

In other work, we examined the possibility of national contact tracing using cellphone location technology, concluding that such non-law enforcement use would be permissible as a "special needs" search provided the program incorporated privacy safeguards. ${ }^{13}$ Having law enforcement use the same technology without a warrant to punitively enforce stay-at-home orders is a harder constitutional sell - the whole point of a "special needs" search is that it is for a purpose outside the general needs of law enforcement. But this only matters for cellphone location data. The other technologies, such as drones and video cameras, are outside the warrant requirement, and law enforcement could therefore employ them at will. ${ }^{14}$

There were even some scattered reports of these technologies being used. One Connecticut town considered experimenting with fever-detecting drones, but abandoned the proposal due to community opposition. ${ }^{15}$ Several

10 See, e.g., Ferguson, supra note 7 (arguing for limited Fourth Amendment protection supplemented by statutory privacy laws given the strong policy case in favor of limiting facial recognition use). Though some localities have banned law enforcement use of facial recognition, there are comparatively few of these.

11 See Carpenter v. United States, 138 S. Ct. 2206, 2217 (2018).

12 As we mention in the text accompanying note 36 , infra, three quarters of police departments in our sample report at least sometimes using cellphone location data in the course of their normal activities. See also Zack Whittaker, T-Mobile Quietly Reported a Sharp Increase in Police Demands for Cell Tower Data, TeChCRunch (July 12, 2019 12:23 PM) (reporting that in 2018, T-Mobile received over 70,000 requests for historic cell location data, over 27,000 requests for prospective locations, and over 6,000 requests for tower dumps) https://techcrunch.com/2019/07/12/t-mobile-cell-tower-government-demands/ [https://perma.cc/B3A5-S2S6].

${ }_{13}$ Matthew Kugler \& Mariana Oliver, Constitutional Pandemic Surveillance, 112 J. CRIM. L. \& CRIMINOLOGY (forthcoming 2021). (https://papers.ssrn.com/sol3/papers.cfm?abstract_id $=3669232)$ [https://perma.cc/URP3-TX7K].

14 See, e.g., Illinois v. Caballes, 543 U.S. 405, 408 (2005) (“Official conduct that does not 'compromise any legitimate interest in privacy' is not a search subject to the Fourth Amendment.").

${ }^{15}$ See, e.g., Westport Police Said They Will Not Test 'Pandemic Drone' That Can Sense Fevers, Coughing, NBC ConN. (Apr., 23, 2020), https://www.nbcconnecticut.com/news/local /westport-police-said-they-will-not-test-pandemic-drone-that-can-sense-fevers- 
state governments trawled through social media looking for evidence of vacationers failing to respect quarantine orders, sometimes issuing fines. ${ }^{16}$ And, on the non-law enforcement front, both news organizations and public policy experts used cellphone location data to track the movements of large groups of people and confirm whether regions were respecting stay-at-home orders. ${ }^{17}$

There was also some conventional enforcement of social distancing guidelines. Police in New York City and Chicago, for instance, both cited people for masking and distancing violations early in the pandemic and then later abandoned these efforts. ${ }^{18}$ Even these short-lived efforts were not without controversy. Citation data suggested that guidelines were enforced more severely against people from minority communities, for example. ${ }^{19}$

We know that many of these surveillance techniques, especially cellphone location tracking, drones, and facial recognition, were used for

coughing/2260023/ [https://perma.cc/6UB7-XUE9]; Alex Williams, The Drones Were Ready for this Moment, N.Y. TIMES (May 23, 2020) https://www.nytimes.com/2020/05/23/style/dro nes-coronavirus.html [https://perma.cc/K677-XFL5].

${ }^{16}$ Lisa Kubota, Social Media Proves a Powerful Tool in Cracking Down on Quarantine Violations, HAw. News Now (May 19, 2020, 7:45 PM), https://www.hawaiinewsnow.com/ 2020/05/20/recent-changes-have-beefed-up-enforcement-traveler-quarantine/

[https://perma.cc/WR2T-P6WX]; Chicago Will Check Social Media to Help Enforce Travel Order: CDPH Commissioner, NBC CHI. (Aug. 4, 2020), https://www.nbcchicago.com/news/ local/chicago-will-check-social-media-to-help-enforce-travel-order-cdph-

commissioner/2316577/ [https://perma.cc/QU5G-ZHWW].

17 Justine Coleman, Apple Now Sharing Mobility Data from Apple Maps, THE HiLl (Apr. 14, 2020, 3:28 PM), https://thehill.com/policy/technology/technology/492763-apple-nowsharing-mobility-data-from-apple-maps-to-help-public [https://perma.cc/H5GZ-5MVD]; Jason Murdock, Mobile Phone Location Data of Florida Beachgoers During Spring Break Tracked to Show Potential Coronavirus Spread, Newsweek, (Mar. 27, 2020, 11:11 AM), https://www.newsweek.com/x-mode-tectonix-coronavirus-heat-map-tracking-mobile-datacovid-19-spring-break-1494663 [https://perma.cc/KX8S-ENYF].

18 Martin Kaste, Police Back Off From Social Distancing Enforcement, NPR (May 15, 2020, 4:58 PM), https://www.npr.org/2020/05/15/857144397/police-back-off-from-socialdistancing-enforcement [https://perma.cc/2EWY-H9RS]; Maxwell Evans and Kelly Bauer, Chicago Police Only Arrested People For Social Distancing Violations on the South and West Sides, Data Shows, Block Club CHI. (May 26, 2020, 3:20 PM), https://blockclubchicago.org/ 2020/05/26/chicago-police-only-arrested-people-for-social-distancing-on-the-south-andwest-sides-data-shows/ [https://perma.cc/5QAW-PBHP].

19 See Evans \& Bauer, supra note 18; Ashley Southall, Scrutiny of Social-Distance Policing as 35 of 40 Arrested Are Black, N.Y. Times (May 7, 2020), https://www.nytimes.com /2020/05/07/nyregion/nypd-social-distancing-race-coronavirus.html [https://perma.cc/S9VG3775]; Janell Ross, Pattern of Uneven Social Distancing Enforcement Coming Into View, Civil Rights Experts Say, NBC News (May 28, 2020, 12:05 PM), https://www.nbcnews.com/ news/nbcblk/pattern-uneven-social-distancing-enforcement-coming-view-civil-rightsexperts-n1216506 [https://perma.cc/VAL9-3PST]. 
COVID containment overseas with apparent success. ${ }^{20}$ We also know that many of these, except for cellphone tracking, could be employed domestically without running afoul of the Constitution. And we know that at least a few departments used or thought about using them. ${ }^{21}$

But there is some reason to think that all of these enforcement and monitoring actions were rare in the United States. In New York, for instance, reporters pointed out that social media readily showed that people were not respecting 14-day quarantine orders-with no particular government sanction. ${ }^{22}$ And, though many municipalities own drones, have experience with cellphone tracking, and possess a bewildering array of other technological tools ranging from video cameras to facial recognition, there were remarkably few stories of them being used. ${ }^{23}$ This is surprising given the vast number of local law enforcement agencies in the United Statesapproximately $16,000 .{ }^{24}$ Though some of them may have done many things to enforce COVID guidelines - generating isolated headlines - there is no clear evidence that most did so.

This brings us to the central question of the present research: what did local law enforcement do in the spring and summer of 2020? Constitutionally, they could do much. Internationally, there were many examples of comparable countries doing much. Is it the case that American departments instead did little?

${ }^{20}$ See, e.g., Moran Amit, Heli Kimhi, Tarif Bader, Jacob Chen, Elon Glassberg \& Avi Benov, Mass-surveillance Technologies to Fight Coronavirus Spread: the Case of Israel, 26 NATURE MEDicine 1167, 1167-69 (2020) (describing the efficacy of Israel's cellphone contact tracing); Derek Thompson, What's Behind South Korea's COVID-19 Exceptionalism? ATLANTIC (May 6, 2020) https://www.theatlantic.com/ideas/archive/2020/05/whats-south-kor eas-secret/611215/ [https://perma.cc/YLG8-K6YR] (describing the success of South Korea in reining in its initial high COVID case count through rapid testing and extensive technological surveillance); Fahim, Kim \& Hendrix, supra note 5 (describing the experiences of several jurisdictions, including South Korea and Singapore, with tech-enabled contact tracing and isolation monitoring).

21 See, e.g., supra notes 15-16.

22 Alyson Krueger, New York Has A 14-Day Quarantine. Many New Yorkers Are Ignoring It, N.Y. TiMES (Aug. 16, 2020), https://www.nytimes.com/2020/08/16/nyregion/coronavirusquarantine-nyc.html [https://perma.cc/4DYY-G3CM].

${ }^{23}$ See, e.g., Nena Beecha, Mass Surveillance to Track the Coronavirus Threatens Black and Brown Communities, TeEN Vogue (June 2, 2020) https://www.teenvogue.com/story/ mass-surveillance-coronavirus [https://perma.cc/6B7Y-Z43E] (expressing great concern over use of mass surveillance but citing only occasional use of drones domestically).

${ }^{24}$ Brian A. Reaves, Hiring and Retention of State and Local Law Enforcement Officers, 2008 - Statistical Tables, U.S. Dep't of Just.: Bureau of Just. Stat., (Oct. 2012), https://www.bjs.gov/content/pub/pdf/hrslleo08st.pdf [https://perma.cc/3GRS-FAPU]. 


\section{SURVEY OF LOCAL POLICE DEPARTMENTS}

In collaboration with CivicPulse, we conducted a survey of local police departments between June 16 and July 3, 2020 to evaluate how they responded to COVID-19. Specifically, we sought to determine what the departments were trying to do, with what tools, and why. Participants were randomly chosen from a universe consisting of the heads of law enforcement of U.S. local governments with populations of over 1,000 residents plus an existing police department. ${ }^{25}$ Data from the U.S. Census Bureau's Census of Governments (2017) reports 38,779 general purpose local governments across the U.S., a figure that includes municipal, township, and county government units. ${ }^{26}$ In total, we received responses that answered the key COVID questions from 370 jurisdictions. ${ }^{27}$ Of these jurisdictions, 62 have a population of fewer than 2,600,146 have a population of between 2,600 and 10,000 , and 162 have a population of 10,000 or more. The survey first asked about law enforcement technology use generally before focusing specifically on the issue of COVID-19 enforcement. The more general technology results will be the subject of a forthcoming paper.

For the main analyses reported below, ${ }^{28}$ we weighted responses at the county level to account for differences between the sampled jurisdictions and national averages on benchmark measures. A probability weight was created with a post-stratification raking procedure using Census and election data. ${ }^{29}$

${ }^{25}$ CivicPulse defines a jurisdiction as a county, municipality, or township. For context, "the average local jurisdiction population in the United States is 6,200" people. Wendell Cox, America is More Small Town Than We Think, New GeOgraphy (Sept. 10, 2008), https://www.newgeography.com/content/00242-america-more-small-town-we-think

[https://perma.cc/K4JS-EY68] (citing data from the 2002 Census of Governments).

${ }^{26}$ U.S. Census Bureau, 2017 Census of Governments tbl. 3 (2017), https://www.census.gov/data/tables/2017/econ/gus/2017-governments.html

[https://perma.cc/SE4H-GYEZ].

27 The recruitment email specified that heads of departments should take the online survey themselves, or, if appropriate, they should forward it to another agency official more knowledgeable about the issues addressed by the survey. Approximately $80 \%$ of the 460 starting the survey completed it, which is why the portion of the sample relevant to the COVID analysis is 370 . Of the 370 respondents in the COVID sample, only $11.4 \%$ self-identified as something other than "head of the department."

${ }^{28}$ Specifically, results are weighted for the analyses in Table 1, reporting the overall frequency of enforcement and encouragement actions, and the frequency of protests analysis on page *11. All other analyses are unweighted because they are performed on a subset of the data. As can be seen in Table 1A in the Appendix, weighting barely affected results.

${ }^{29}$ Variables included: proportion of residents 25 or older with a 4-year college degree (taken from the 2015 American Community Survey); total number of residents (same); proportion of votes for Donald Trump in 2016 (election results); proportion of white residents (same); urbanicity (taken from the 2010 census); and police spending (taken from the 2017 US Census of Governments). 
This procedure is adapted from the methodology outlined by Matthew DeBell and Jon Krosnick for the American National Elections Study (ANES). ${ }^{30}$

As an initial matter, we asked what role these departments sought to take in enforcing COVID-19 rules. Specifically, we asked whether the department sought compliance with each of three specific types of COVID19 guidelines through "encouragement" actions, such as posting signs, or "enforcement actions," such as issuing fines. As shown in Table 1, most departments reported taking only "encouragement" actions. Less than $15 \%$ of departments reported engaging in any kind of "enforcement" activity (such as issuing fines) for each category of COVID-19 guideline. Departments in larger jurisdictions tended to be more likely to take enforcement actions, however. In larger jurisdictions, enforcement was slightly more common for avoiding large gatherings $(21.0 \%$ for jurisdictions with populations over $10,000,14.4 \%$ for populations between 2,600 and 10,000 , and $11.3 \%$ for populations below 2,600$)$, avoiding in-person work $(21.0 \%, 15.1 \%$, and $6.5 \%$ respectively), and social distancing $(16.0 \%, 13.7 \%$, and $9.7 \%$ respectively). Importantly, these general types of orders were virtually universal. At their height in late April, every state but South Dakota had closed non-essential businesses, and every state but South Dakota, North Dakota, and Utah had either a stay-at-home order or a ban on large gatherings. ${ }^{31}$

Those jurisdictions that reported either not taking any actions or only taking encouragement actions received follow-up questions that asked them to report why they had chosen those courses. ${ }^{32}$ Specifically, they were asked either why they had chosen to take no action (22 of the 370 departments answering this question) or why they had decided to forgo enforcement action in favor of encouragement (260 of the departments).

30 Matthew DeBell \& Jon A. Krosnick, Computing Weights for American National Election Study Survey Data, ANES Technical Report Series, No. nes012427. (2009). Available at https://electionstudies.org/wp-content/uploads/2018/04/nes012427.pdf [https:// perma.cc/W442-MKX9].

31 See, e.g., Cloud, Moran-McCabe, Platt, \& Prood, supra note 1, at 14. Of the six South Dakota departments in our sample, one reported engaging in both enforcement and encouragement, one reported engaging in neither enforcement nor encouragement, and 4 reported some encouragement actions.

32 To receive the "No Action" follow-up, respondents had to select the "Neither" category for all questions. To receive the "Encouragement Only" follow-up, respondents had to select "Encouragement" at least once and never select "Enforcement" or "Both." 
Table 1: Percentage of departments reporting taking "Encouragement" or "Enforcement" actions to promote compliance with COVID-19 guidelines.

\begin{tabular}{|l|c|c|c|c|}
\hline & Encouragement & Enforcement & Both & Neither \\
\hline Avoiding large gatherings & $74.0 \%$ & $1.3 \%$ & $11.7 \%$ & $13.0 \%$ \\
\hline $\begin{array}{l}\text { Avoiding in-person work except } \\
\text { for essential businesses }\end{array}$ & $70.2 \%$ & $2.9 \%$ & $10.2 \%$ & $16.7 \%$ \\
\hline $\begin{array}{l}\text { "Social distancing" in public } \\
\text { (e.g., staying 6 feet apart) }\end{array}$ & $77.7 \%$ & $2.5 \%$ & $10.3 \%$ & $9.5 \%$ \\
\hline
\end{tabular}

Among those whose departments reported taking no action, many said that they believed the guidelines were unnecessary (59.1\%). If this seems surprising given the effects of COVID-19 nationally, recall that at least one sheriff actually barred his deputies and departmental visitors from being masked. ${ }^{33}$ Notably, there were fairly few departments in the "No Action" category — only 22. So, these responses should be interpreted with some caution.

Many more departments were in the "Encouragement Only" category, and in combination, their reasons tell a story. Only $7.3 \%$ of departments reported that another agency had jurisdiction over these orders, so these departments view themselves as the appropriate agencies to be enforcing the guidelines. But their actions nevertheless stop at encouragement, and many felt that they were not receiving guidance from above $(45.0 \%)$ or that they did not need to do more than they were given the level of compliance they were observing in their communities $(41.9 \%)$. More than two-thirds of departments selected at least one of those two options (70.8\%). Importantly, only a small fraction reported that they believed the guidelines were unnecessary $(10 \%)$. Use of encouragement rather than enforcement therefore does not seem to be due to principled disobedience.

Respondents in both the "No Action" and "Encouragement Only" categories did not frequently cite concern with community disapproval as a reason for their preferred policy choice, though community attitudes could easily have informed the guidance the department received from other portions of the government.

33 Caitlin O'Kane, Florida Sheriff Bans Deputies and Visitors From Wearing Face Masks: "This is No Longer a Debate Nor Is It Up For Discussion," CBS News (Aug. 13, 2020), https://www.cbsnews.com/news/florida-sheriff-billy-woods-bands-deputies-wearing-facemasks-marion-county/ [https://perma.cc/9ZJT-PWMF]. 
Table 2: Reasons for adopting particular COVID-19 approaches.

\begin{tabular}{|l|c|c|}
\hline & No action & Encouragement Only \\
\hline Concerns about community disapproval & $18.2 \%$ & $31.9 \%$ \\
\hline Lack of resources or personnel & $31.8 \%$ & $30.8 \%$ \\
\hline $\begin{array}{l}\text { Lack of clear guidelines from local or state } \\
\text { government }\end{array}$ & $36.4 \%$ & $45.0 \%$ \\
\hline Non-compliance has not been an issue & $36.4 \%$ & $41.9 \%$ \\
\hline Another department has jurisdiction & $13.6 \%$ & $7.3 \%$ \\
\hline Guidelines are inappropriate/unnecessary & $59.1 \%$ & $10.0 \%$ \\
\hline Other: 34 & $18.2 \%$ & $13.1 \%$ \\
\hline None of the above & $0.0 \%$ & $8.8 \%$ \\
\hline Total Number of Departments Responding & 22 & 260 \\
\hline
\end{tabular}

Perhaps unsurprising given this lack of enforcement actions was departments' use - or rather, non-use - of surveillance technology for COVID-19 related purposes. Even though the question proposed a list of six different technologies that might be used, $92.1 \%$ of departments reported no use of any special technology for the enforcement of stay-at-home orders or other COVID-19 related purposes. Of those using any technology, the most commonly cited was video cameras (5.9\%). Only 5 of 356 departments (1.4\%) mentioned using facial recognition of any kind, only 4 (1.1\%) reported using each of drones, cellphone location data, and credit card data, and only $2(0.6 \%)$ mentioned using utility data. ${ }^{35}$ And this was not due to any great shyness about use of technology generally. In contrast, $76.2 \%$ of these departments reported using cellphone location data for other purposes such as emergencies or investigations. ${ }^{36}$

Thinking about how certain actors may use these technologies for COVID-19 enforcement reveals a disconnect between regular police practice and the kind of use that would be suited to a pandemic environment. Normal uses of cellphone location tracking for law enforcement would be either

34 Two of the four departments selecting this response in the "no action" column indicated that they believed that enforcement would be unconstitutional in most cases. For the encouragement only column, five of thirty-four departments leaving comments cited constitutional problems.

35 The number of responses varied somewhat by question in this survey. 356 answered the technology question and 370 the COVID enforcement question.

36 This data will be discussed more fully in forthcoming work by the authors Kugler \& Oliver, Constitutional Pandemic Surveillance, supra note 13. 
tracing a particular person's movement or gathering a list of people who had been near a particular location at a particular time. ${ }^{37}$ Those are historical cellphone location data, the subject of the Supreme Court's 2018 Carpenter decision, and tower dumps, respectively. Major cellphone companies have established procedures for fielding such requests. ${ }^{38}$

One could build an apparatus to monitor cellphone location data for quarantine enforcement. It could check where each phone slept each night, whether it left that place and made multiple "stops" out in the world, whether it left the state. But this would be very different than anything American police departments regularly do. When Israel engaged in cellphone tracking for quarantine enforcement, it adapted a program used for counterterrorism. ${ }^{39}$ The American equivalent would be tasking the National Security Agency with COVID-19 related citizen surveillance, rather than the New York Police Department.

As of the spring and early summer of 2020, then, local law enforcement played a relatively minimal role in enforcing COVID-19 related orders. Its role was primarily one of encouragement, and most agencies appear to have been relying on voluntary compliance. The kind of mass surveillance contemplated in other countries was simply beyond American police departments' normal mission.

There was one final role for local police in combating the effects of COVID-19. In early May 2020, before the uptick of Black Lives Matter protests in late May and early June, there was considerable discussion in the media about anti-COVID-19 safety protests. ${ }^{40}$ The respondents in our sample reported that these protests were rare in their localities; only $11.9 \%$ reported having had any protests at all. Again, this experience varied somewhat by the size of the department. Acts of protest were much more common in larger jurisdictions. ${ }^{41}$ Importantly, however, only $1 \%$ of departments reported

37 See, e.g., Whittaker, supra note 12 (reporting on the number of law enforcement requests for this data in 2017 and 2018).

${ }^{38} \mathrm{Id}$.

39 Monica Chin, Israel Is Using Cellphone Data to Track the Coronavirus, THE Verge (Mar. 17, 2020, 1:52 PM), https://www.theverge.com/2020/3/17/21183716/coronaviruscovid-19-israel-natanyahu-cellphone-data-tracking [https://perma.cc/LK65-WJVF]; see also Amit,. Kimhi, Bader, Chen, Glassberg \& Benov, supra note 20.

${ }^{40}$ See, e.g., Lois Beckett, Armed Protestors Demonstrate Against COVID-19 Lockdown at Michigan Capital, GuARDian (Apr. 30, 2020), https://www.theguardian.com/usnews/2020/apr/30/michigan-protests-coronavirus-lockdown-armed-capitol [https://perma.cc/6AFW-9FS2].

$4117.6 \%$ of jurisdictions with a population over 10,000 reported protests, compared to $13.4 \%$ of jurisdictions with a population between 2,600 and 10,000 and $6.6 \%$ of jurisdictions with a population below 2,600 . 
protests that had "posed a threat to public safety" in the eyes of the department. Controlling a highly disruptive protest would be within the routine mission of a police department. But anti-COVID-19 safety protests were both rare and rarely disruptive, even from the perspective of law enforcement. ${ }^{42}$

\section{CONCLUSION}

As of the early summer of 2020, there was no national effort to couple pandemic surveillance against COVID-19 with police enforcement of stayat-home and social distancing orders. This lack of police activity was not due to any inherent legal restriction - constitutionally, much could have been done to monitor compliance with these orders. Many local police departments, however, reported feeling that further action was not needed. In contrast to Israel and South Korea, the United States has not punitively employed the tools of mass surveillance in the pandemic domain. But we cannot predict whether law enforcement will take a more expansive role to combat COVID-19 in the spring of 2021, or to fight COVID-24 in the spring of 2025 .

42 Further information about the frequency of protests is available in the CivicPulse whitepaper Patterns of Local Protests against COVID-19 Restrictions across America, https://www.civicpulse.org/protest-report [https://perma.cc/V8LC-UGYD] (October 2020). 
APPENDIX

Table 1A: Unweighted percentage of departments reporting taking "Encouragement" or "Enforcement" actions to promote compliance with COVID-19 guidelines.

\begin{tabular}{|l|l|l|l|c|}
\hline & Encouragement & Enforcement & Both & Neither \\
\hline Avoiding large gatherings & $74.1 \%$ & $2.4 \%$ & $14.3 \%$ & $9.2 \%$ \\
\hline $\begin{array}{l}\text { Avoiding in-person work except } \\
\text { for essential businesses }\end{array}$ & $71.1 \%$ & $4.1 \%$ & $12.2 \%$ & $12.7 \%$ \\
\hline $\begin{array}{l}\text { "Social distancing" in public } \\
\text { (e.g., staying 6 feet apart) }\end{array}$ & $78.1 \%$ & $1.9 \%$ & $12.2 \%$ & $7.8 \%$ \\
\hline
\end{tabular}

The unweighted analysis of protest prevalence shows that $13.8 \%$ experienced protests, including $0.8 \%$ that the department thought were a threat to public safety. 